\title{
Peran Kepemimpinan, Lingkungan Kerja Dan Kompetensi Terhadap Perilaku Kinerja Dengan Motivasi Sebagai Variabel Intervening
}

\author{
I Gusti Ayu Agung \\ Sekolah Tinggi Pariwisata Sahid Surakarta \\ Email: idabagusputudiratsaha@gmail.com
}

\begin{abstract}
The study aims to determine the effect of leadership, work environment and competence on performance through work motivation as an intervening variable for employees of Sahid Jaya Surakarta Hotel. Collection by questionnaire, and observation. Sampling using purposive sampling. Data analysis uses path analysis, $t$ test, total $F$ and $R^{2}$. The results of leadership and work environment variables have an effect but not significant, while the competency has a significant effect on the motivation. Leadership, work environment and competence are influential but not significant, while motivation has a significant effect on the performance. F test results can be concluded together variables namely leadership, work environment, competence and motivation affect performance. The total $R^{2}$ value of 0.849 means that Sahid Jaya Solo Hotel employees are explained by leadership, work environment and competence with work motivation as an intervening variable of $84.9 \%$ and the remaining $15.1 \%$ is explained by other variables outside the research model, for example discipline and incentive variables. The results of path analysis show that the variables chosen in improving performance are by increasing competence, because competence is the most dominant variable on performance, with the regression efficiency $=1.018$ where the highest coefficient among others.
\end{abstract}

Keywords: leadership, work environment, competence, motivation, performance

\begin{abstract}
ABSTRAK
Penelitian ini bertujuan untuk mengetahui pengaruh kepemimpinan, lingkungan kerja dan kompetensi terhadap kinerja melalui motivasi kerja sebagai variabel intervening pada karyawan Hotel Sahid Jaya Surakarta. Pengumpulan dengan angket, dan observasi. Pengambilan sampel menggunakan purposive sampling. Analisis data menggunakan analisis jalur, uji t, F total dan $\mathrm{R}^{2}$. Hasil variabel kepemimpinan dan lingkungan kerja berpengaruh tetapi tidak signifikan, sedangkan kompetensi berpengaruh signifikan terhadap motivasi. Kepemimpinan, lingkungan kerja dan kompetensi berpengaruh tetapi tidak signifikan, sedangkan motivasi berpengaruh signifikan terhadap kinerja. Hasil uji F dapat disimpulkan secara bersama-sama variabel yaitu kepemimpinan, lingkungan kerja, kompetensi dan motivasi berpengaruh terhadap kinerja. Nilai $\mathbf{R}^{2}$ total sebesar 0,849 artinya karyawan Hotel Sahid Jaya Solo dijelaskan oleh kepemimpinan, lingkungan kerja dan kompetensi dengan motivasi kerja sebagai variabel intervening sebesar $84,9 \%$ dan sisanya $15,1 \%$ dijelaskan oleh variabel lain di luar model penelitian, misalnya disiplin. dan variabel insentif. Hasil analisis jalur menunjukkan bahwa variabel yang dipilih dalam meningkatkan kinerja adalah dengan meningkatkan kompetensi, karena kompetensi merupakan variabel yang paling dominan terhadap kinerja, dengan efisiensi regresi $=$ 1,018 dimana koefisien tertinggi diantara yang lain.
\end{abstract}

Kata kunci: kepemimpinan, lingkungan kerja, kompetensi, motivasi, kinerja

\section{PENDAHULUAN}

Bermunculan hotel dengan layanan berbintang di Kota Solo, menjadikan Hotel Sahid Jaya mau tidak mau mengalami penurunan tingkat hunian (ocupancy). Hal ini harus benar- benar menjadi perhatian yang serius dari pihak hotel, untuk bagaimana mengupayakan kembali meningkatkan kualitas layanan yang diberikan. Adanya keinginan untuk mempunyai karyawan dengan kinerja yang tinggi sukar untuk tercapai. Hal ini menjadi dasar Hotel Sahid Jaya untuk mencapai terciptanya karyawan dengan kinerja yang baik. Faktor yang dipandang mampu mendukung kinerja karyawan antara lain, motivasi, kepemimpinan, lingkungan kerja dan Kompetensi karyawan (Adriyanto \& Subakti, 2018). Perilaku tersebut akan memberikan imbas yang tidak kecil terhadap kinerja karyawan Hotel Sahid Jaya Solo.

Organisasi baik pemerintahan maupun swasta demikian juga Hotel Sahid Jaya Solo membutuhkan pemimpin yang mampu mempengaruhi perilaku pegawainya. Keberadaan pemimpin akan diakui apabila 
dapat berpengaruh dan mengarahkan bawahannya kearah pencapaian tujuan instansi (Daswati, 2012). Dengan demikian faktor kepemimpinan merupakan salah satu dari fungsi manajemen yang penting (Flippo, 2004). Hotel Sahid Jaya dengan kondisi lingkungan yang ada sekarang berpengaruh terhadap kinerja kerja karyawan. Keberadaan lingkungan kerja Hotel Sahid Jaya yang baik akan memberikan kenyamanan baiksecara pribadi maupun dalam membangkitkan semangat kerja pegawai sehingga dapat mengerjakan tugas-tugas dengan baik.

Peningkatan kinerja karyawan juga dapat dipengaruhi oleh kompetensi yang dimiliki karyawan dalam menjalankan setiap job descriptionnya. Keberadaan karyawan yang memiliki kompetensi sesuai tugasnya ini sangat penting di Hotel Sahid Jaya, karena dengan kompetensi kerja yang baik yang dimiliki oleh karyawan, akan dapat memberikan layanan yang memuaskan terhadap tamu yang menginap di Hotel Sahid Jaya.

Terkait kompetensi karyawan dalam upaya memberikan layanan di Hotel Sahid Jaya sesuai dengan apa yang diharapkan dalam pelaksanaannya diperlukan upaya untuk terus meningkatkan kemampuan seperti diadakannya pendidikan dan pelatihan bagi para karyawan dan masih minumnya pengalaman kerja yang miliki para karyawan sehingga mempengaruhi kompetensinya.

Penanaman motivasi pada diri karyawan baik yang dilakukan diri sendiri maupun oleh instansi sangat berperan penting dalam meningkatkan kinerja karyawan. Salah satu yang menjadi motivasi seseorang untuk bekerja karena adanya kebutuhan. Karyawan yang memiliki motivasi yang tinggi, tidak akan cepat putus asa dan pantang menyerah dalam setiap pekerjaan yang dilakukannya (Hasibuan, 2009). Dengan demikian, adanya motivasi kerja yang tinggi maka kinerja juga akan meningkat.

Berdasarkan hasil-hasil penelitian yang telah dilakukan, bahwa kepemimpinan berpengaruh positif dan signifikan terhadap motivasi (Aryono, 2017). Kepemimpinan berpengaruh negatif dan tidak signifikan terhadap kinerja pegawai (Marjaya \& Pasaribu, 2019). Kepemimpinan dengan variabel intervening komitmen organisasi dan motivasi berpengaruh signifikan terhadap kinerja (Santris, 2019). Kepemimpinan tidak berpengaruh signifikan terhadap kinerja (Putra et al., 2019). Lingkungan kerja berpengaruh tidak signifikan terhadap kinerja (Siahaan \& Bahri, 2019). Dewi Kartikasari (2015) dalam penelitiannya menyatakan bahwa kompetensi berpengaruh signifikan terhadap kinerja (Siregar, 2020), kompetensi berpengaruh tidak signifikan terhadap kinerja (Supiyanto, 2015).

Berdasarkan adanya alasan adanya research gap yang telah diungkapkan dalam paragraf sebelumnya ,penelitian ini dilakukan, dan permasalahan yang telah ditemukan saat wawancara kepada HRD Hotel Sahid Jaya. Tujuan dalam penelitian ini adalah untuk menganalisis peran Kepemimpinan, Lingkungan Kerja Dan Kompetensi Yang Berdampak Terhadap Perilaku Kinerja Dengan Motivasi sebagai Variabel Intervening Pada Pegawai Hotel Sahid Jaya Solo.

\section{LANDASAN TEORI}

Kinerja

Kinerja adalah hasil kerja secara kualitas dan kuantitas yang dicapai oleh seorang pegawai dalam melaksanakan tugasnya sesuai dengan tanggung jawab yang diberikan kepadanya (Muzakki \& Ariyanto, 2019). Pada hakikatnya kinerja merupakan prestasi yang dicapai oleh seseorang dalam melaksanakan tugasnya atau pekerjaannya seseuai dengan standar dan kriteria yang ditetapkan untuk pekerjaan itu. Indikator kinerja karyawan meliputi kualitas, kuantitas, ketepatan, efektifitas, kemandirian (Nugroho et al., 2013). 
Motivasi

Motivasi merupakan hal yang menyebabkan, menyalurkan dan mendukung perilaku manusia, supaya mau bekerja giat dan antusias mencapai hasil yang optimal (Astuti, 2017). Menurut Rivai (2004:22) berpendapat bahwa motivasi adalah serangkaian sikap dan nilai-nilai yang mempengaruhi individu untuk mencapai hal yang spesifik sesuai dengan tujuan individu. Indikator motivasi kerja meliputi kinerja, penghargaan, tantangan, tanggungjawab, pengembangan, keterlibatan, kesempatan (Bahri \& Chairatun Nisa, 2017)

Kepemimpinan

Kepemimpinan adalah suatu usaha atau kegiatan yang dilakukan oleh seseorang dalam hubungan antar manusia untuk mempengaruhi orang lain dan diarahkan melalui proses komunikasi dengan tujuan agar orang lain (mungkin seorang atau sekelompok orang) maumelakukan sesuatu dalam usaha untuk mencapai apa yang diinginkan oleh orang yang mempengaruhi atau oleh mereka semua (Ruky, 2002). Indikator kepemimpinan meliputi : situasi saling mempercayai, penghargaan terhadap ide bawahan, memperhitungkan perasaan para bawahan, perhatian pada kenyamanan kerja bagi para bawahan, perhatian pada kesejahteraan bawahan, pengakuan atas status para bawahan secara tepat dan proposional, memperhitungkan faktor kepuasan kerja para bawahan dalam menyelesaikan tugas-tugas yang dipercayakan padanya (Andayani \& Tirtayasa, 2019)

\section{Lingkungan Kerja}

Kondisi lingkungan kerja dikatakan baik atau sesuai apabila manusia dapat melaksanakan kegiatan secara optimal, sehat, aman, dan nyaman (Febrian et al., 2019). Lingkungan kerja dipengaruhi oleh beberapa faktor-faktor yang dapat mempengaruhi terbentuknya lingkungan kerja yaitu penerangan/cahaya, suhu udara, suara bising, keamanan kerja dan hubungan karyawan (Sabaruddin \& Marissa, 2018).

\section{Kompetensi}

Kompetensi adalah pengetahuan dan keahlian yang dimiliki oleh sesorang untuk menyelesaikan tugas yang menjadi tanggungjawabnya (Ramadhanty et al., 2019). Kompetensi yang dimiliki karyawan ini secara individual harus mampu mendukung pelaksanaan strategi organisasi dan mampu mendukung setiap perubahan yang dilakukan manajemen. Indikator kompetensi meliputi pengetahuan, pemahaman, kemampuan, nilai, sikap, dan minat (Basori et al., 2017).

\section{Kerangka Berpikir}

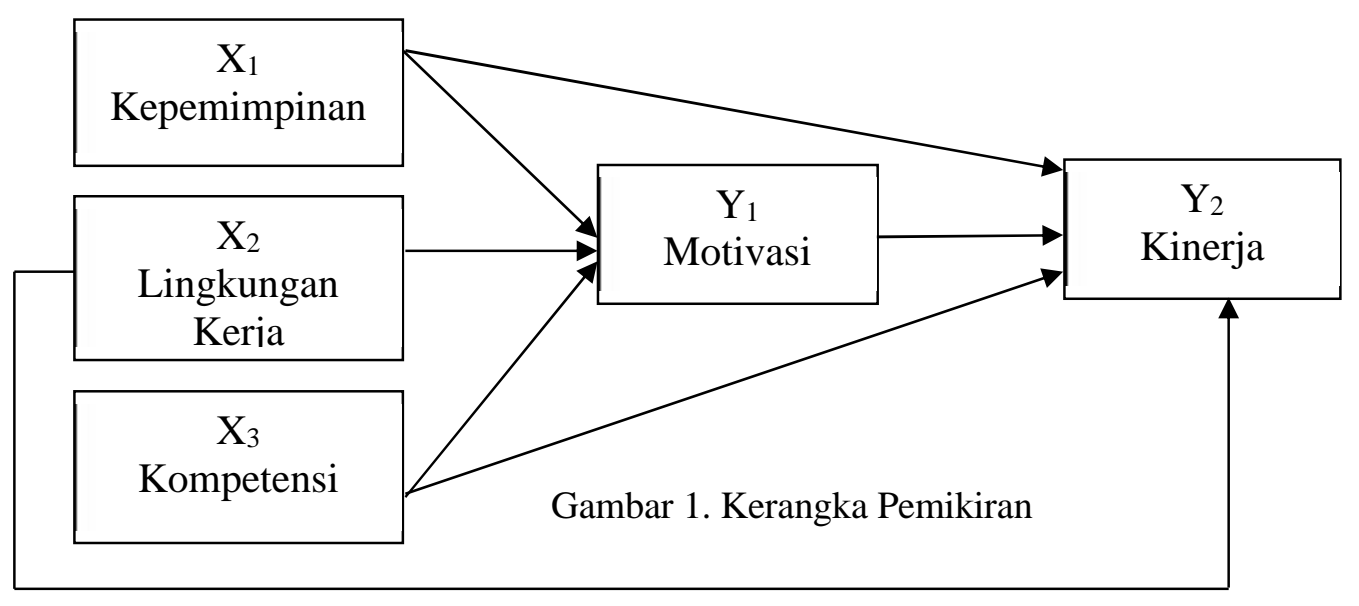




\section{METODE PENELITIAN}

Penelitian ini termasuk penelitian penjelasan (explanatory research), yang akan menjelaskan hubungan kausal antara variabel bebas atau independent variabel meliputi variabel kepemimpinan, lingkungan kerja dan kompetensi. Variabel intervening dalam penelitian ini adalah motivasi. Variabel dependen adalah kinerja pegawai. Lokasi Penelitian di Hotel Sahid Jaya Solo. Populasi penelitian yaitu seluruh karyawan Hotel Sahid Jaya yang berjumlah 112 pegawai. Sampel berjumlah 50 responden dengan teknik sampel purposive sampling yaitu karyawan yang pendidikannya minimal SLTA. Teknik pengumpulan data menggunakan kuesioner, observasi dan dokumentasi. Data dianalisis dengan statistik deskriptif, uji instrumen penelitian dan uji hipotesis dengan path analysis dan uji korelasi.

\section{HASIL DAN PEMBAHASAN}

\section{Karakteristik Responden}

Mayoritas responden dalam penelitian ini berjenis kelamin laki-laki sebanyak 34 orang $(68,0 \%)$ sedangkan wanita sejumlah 16 orang (32,0\%). Usia responden paling banyak 36-45 tahun sebanyak 19 orang (38,0\%), kemudian usia 25-35 tahun sebanyak 17 orang (34,0\%), dan 46-55 tahun sebanyak 14 orang $(28,0 \%)$. Tingkat pendidikan paling banyak yaitu D3 sejumlah 19 orang $(38,0 \%)$, kemudian S1 sebanyak 13 orang (26,0\%), SMA sebanyak 11 orang $(22,0 \%)$ dan S2 sebanyak 7 orang (14,0\%).

\section{Hasil dan Analisis}

\section{Uji Instrumen Penelitian}

Hasil uji validitas pada variabel kepemimpinan (x1) sebanyak 10 item pertanyaan dinyatakan valid artinya semua item pertanyaan pada variabel kepemimpinan (x1) dapat digunakan sebagai instrumen penelitian selanjutnya. Variabel lingkungan kerja (x2) sebanyak 10 item pertanyaan dinyatakan valid artinya semua item pertanyaan pada variabel lingkungan kerja (x2) dapat digunakan sebagai instrumen penelitian selanjutnya. Variabel kompetensi (x3) sebanyak 12 item pertanyaan dinyatakan valid artinya semua item pertanyaan pada variabel kompetensi (x3) dapat digunakan sebagai instrumen penelitian selanjutnya. Variabel motivasi (y1) sebanyak 20 item pertanyaan dinyatakan valid artinya semua item pertanyaan pada variabel motivasi $(\mathrm{y} 1)$ dapat digunakan sebagai instrumen penelitian selanjutnya. Variabel kinerja (y2) sebanyak 10 item pertanyaan dinyatakan valid artinya semua item pertanyaan pada variabel kinerja (y2) dapat digunakan sebagai instrumen penelitian selanjutnya.

Hasil uji reliabilitas diketahui bahwa nilai alpha cronbach variabel kepemimpinan (x1) sebesar 0,806, variabel lingkungan kerja (x2) sebesar 0,872, variabel kompetensi (x3) sebesar 0,914, variabel motivasi sebesar 0,913 dan variabel kinerja sebesar 0,804 . Variabel dalam penelitian ini dapat dikatakan bahwa butirbutir pertanyaan seluruh variabel dalam keadaan reliabel.

\section{Hasil Uji Hipotesis}
A. Uji t
1) Hasil uji t persamaan 1

Tabel 1. Uji t persamaan 1

\begin{tabular}{|c|c|c|c|c|c|c|}
\hline \multicolumn{7}{|c|}{ Coefficients } \\
\hline \multirow[b]{2}{*}{ Mode } & & \multicolumn{2}{|c|}{$\begin{array}{c}\text { Unstandardized } \\
\text { Coefficients }\end{array}$} & \multirow{2}{*}{$\begin{array}{c}\begin{array}{c}\text { Standardized } \\
\text { Coefficients }\end{array} \\
\text { Beta }\end{array}$} & \multirow[b]{2}{*}{$t$} & \multirow[b]{2}{*}{ Sig. } \\
\hline & & $B$ & Std. Error & & & \\
\hline \multirow[t]{4}{*}{1} & (Constant) & 10,039 & 8,073 & & 1,244 &, 220 \\
\hline & Kepemimpinan &, 010 & 231 & ,005 & ,043 & ,966 \\
\hline & Lingkungan Kerja & 468 & 221 & ,259 & 2,121 & ,039 \\
\hline & Kompetensi & 1,054 & ,186 &, 626 & 5,678 &, 000 \\
\hline
\end{tabular}


Tabel 1 menunjukkan bahwa hasil regresi persamaan pertama diketahui $t_{\text {hitung }}$ variabel Kepemimpinan sebesar 0,043 dengan nilai signifikan 0,966 > 0,05 berarti variabel Kepemimpinan berpengaruh tetapi tidak signifikan terhadap motivasi Kerja, sehingga hipotesis 1 tidak terbukti. $t_{\text {hitung }}$ variabel lingkungan kerja sebesar 2,121 dengan nilai signifikan 0,039>0,05 berarti variabel lingkungan berpengaruh tetapi tidak signifikan terhadap motivasi Kerja, sehingga hipotesis 2 tidak

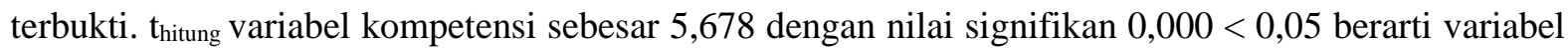
kompetensi berpengaruh signifikan terhadap motivasi kerja, sehingga hipotesis 3 terbukti

2) Hasil uji t persamaan 2

Tabel 2. Uji t persamaan 2

Coefficients $s^{a}$

\begin{tabular}{|c|c|c|c|c|c|c|}
\hline \multirow{2}{*}{\multicolumn{2}{|c|}{ Model }} & \multicolumn{2}{|c|}{$\begin{array}{l}\text { Unstandardized } \\
\text { Coefficients }\end{array}$} & \multirow{2}{*}{$\begin{array}{c}\begin{array}{c}\text { Standardized } \\
\text { Coefficients }\end{array} \\
\text { Beta }\end{array}$} & \multirow[b]{2}{*}{$t$} & \multirow[b]{2}{*}{ Sig. } \\
\hline & & $\mathrm{B}$ & Std. Error & & & \\
\hline \multirow[t]{5}{*}{1} & (Constant) & 5,151 & 4,865 & & 1,059 & 295 \\
\hline & Kepemimpinan & ,284 & , 137 & 270 & 2,079 & ,043 \\
\hline & Lingkungan Kerja & 016 & ,137 & 017 & ,116 & ,908 \\
\hline & Kompetensi & ,063 & , 143 & ,073 & ,442 & ,661 \\
\hline & Motivasi & ,258 & ,087 & ,503 & 2,952 & ,005 \\
\hline
\end{tabular}

a. Dependent Variable: Kinerja

Tabel 2 menunjukkan bahwa nilai signifikan 0,043>0,05 berarti variabel Kepemimpinan berpengaruh tetapi tidak signifikan terhadap Kinerja, sehingga hipotesis 4 tidak terbukti. Nilai signifikan 0,908 >0,05 berarti variabel lingkungan berpengaruh tetapi tidak signifikan terhadap kinerja, sehingga hipotesis 5 tidak terbukti. Nilai signifikan 0,661>0,05 berarti variabel kompetensi berpengaruh tetapi tidak signifikan terhadap kinerja, sehingga hipotesis 6 tidak terbukti. Nilai signifikan 0,005 > 0,05 berarti variabel motivasi berpengaruh signifikan terhadap kinerja, sehingga hipotesis 7 terbukti

\section{B. Uji F}

Tabel 3. Hasil Uji F Persamaan 1

\begin{tabular}{|c|c|c|c|c|c|c|}
\hline \multicolumn{7}{|c|}{ ANOVA $^{b}$} \\
\hline Model & & $\begin{array}{c}\text { Sum of } \\
\text { Squares }\end{array}$ & df & Mean Square & $\mathrm{F}$ & Sig. \\
\hline 1 & $\begin{array}{l}\text { Regression } \\
\text { Residual } \\
\text { Total }\end{array}$ & $\begin{array}{r}1905,992 \\
978,328 \\
2884,320\end{array}$ & $\begin{array}{r}3 \\
46 \\
49\end{array}$ & $\begin{array}{r}635,331 \\
21,268\end{array}$ & 29,873 &, $000^{a}$ \\
\hline
\end{tabular}

a. Predictors: (Constant), Kompetensi, Kepemimpinan, Lingkungan Kerja

b. Dependent Variable: Motivasi

Hasil uji secara serempak (Uji F) pada persamaan pertama diketahui besarnya nilai $\mathrm{F}=29,873$ signifikansi $0,000<0,05$. Sehingga dapat disimpulkan secara bersama-sama variabel kepemimpinan, lingkungan kerja dan komptensi mempengaruhi motivasi.

Tabel 4. Hasil Uji F Persamaan 2

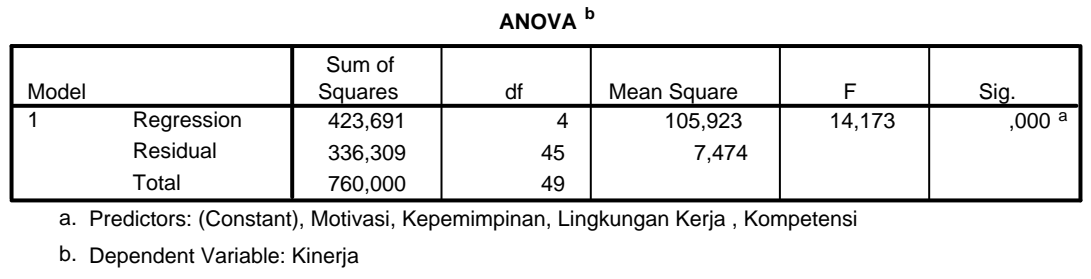


Hasil uji secara serempak (Uji F) pada persamaan kedua diketahui besarnya nilai $\mathrm{F}=14,173$ signifikansi $0,000<0,05$. Sehingga dapat disimpulkan secara bersama-sama variabel yaitu kepemimpinan, lingkungan kerja, komptensi dan motivasi mempengaruhi Kinerja.

\section{Uji Koefisien Determinasi}

Tabel 5. Hasil Koefisien Determinasi Persamaan 1

\begin{tabular}{|l|c|c|c|c|}
\multicolumn{5}{c|}{ Model Summary } \\
\hline Model & $\mathrm{R}$ & R Square & $\begin{array}{c}\text { Adjusted } \\
\text { R Square }\end{array}$ & $\begin{array}{c}\text { Std. Error of } \\
\text { the Estimate }\end{array}$ \\
\hline 1 &, $813^{\mathrm{a}}$ &, 661 &, 639 & 4,612 \\
\hline
\end{tabular}

a. Predictors: (Constant), Kompetensi, Kepemimpinan, Lingkungan Kerja

Tabel 6. Hasil Koefisien Determinasi Persamaan 2

\begin{tabular}{|l|r|r|r|c|}
\multicolumn{7}{c|}{ Model Summary } \\
\hline Model & $\mathrm{R}$ & R Square & $\begin{array}{c}\text { Adjusted } \\
\text { R Square }\end{array}$ & $\begin{array}{c}\text { Std. Error of } \\
\text { the Estimate }\end{array}$ \\
\hline 1 &, $747^{\mathrm{a}}$ &, 557 &, 518 & 2,734 \\
\hline
\end{tabular}

a. Predictors: (Constant), Motivasi, Kepemimpinan, Lingkungan Kerja, Kompetensi

b. Dependent Variable: Kinerja

Dari persamaan 1 dan persamaan 2 tersebut maka didapatkan nilai Koefisien determinasi total $\left(\mathrm{R}^{2}\right)$. Nilai $\mathrm{R}^{2}$ total sebesar 0,849 artinya karyawan Hotel Sahid Jaya Solo dijelaskan oleh kepemimpinan, lingkungan kerja dan kompetensi dengan motivasi kerja sebagai variabel intervening sebesar $84,9 \%$ dan sisanya sebesar $15,1 \%$ dijelaskan variabel lain diluar model penelitian, misal variabel kedisiplinan dan insentif.

\section{Analisa Korelasi}

Tabel 7. Tabel Hasil Uji Korelasi

Correlations

\begin{tabular}{|c|c|c|c|c|c|c|}
\hline & & $\begin{array}{c}\text { Kepemim } \\
\text { pinan }\end{array}$ & $\begin{array}{c}\text { Lingkungan } \\
\text { Kerja }\end{array}$ & Kompetensi & Motivasi & Kinerja \\
\hline \multirow[t]{3}{*}{ Kepemimpinan } & Pearson Correlation & 1 &, $626^{* *}$ &, $501^{* *}$ &, $481^{* *}$ &, $559^{* \star}$ \\
\hline & Sig. (2-tailed) & & ,000 & ,000 & ,000 & ,000 \\
\hline & $\mathrm{N}$ & 50 & 50 & 50 & 50 & 50 \\
\hline \multirow[t]{3}{*}{ Lingkungan Kerja } & Pearson Correlation &, $626^{* *}$ & 1 & ,608** &, $643^{* *}$ &, $553^{\star \star}$ \\
\hline & Sig. (2-tailed) &, 000 & &, 000 &, 000 & ,000 \\
\hline & $\mathrm{N}$ & 50 & 50 & 50 & 50 & 50 \\
\hline \multirow[t]{3}{*}{ Kompetensi } & Pearson Correlation &, $501^{\star *}$ & $608^{\star *}$ & 1 &, $786^{* *}$ & $614^{\star \star}$ \\
\hline & Sig. (2-tailed) &, 000 & ,000 & &, 000 & ,000 \\
\hline & $\mathrm{N}$ & 50 & 50 & 50 & 50 & 50 \\
\hline \multirow[t]{3}{*}{ Motivasi } & Pearson Correlation &, $481^{\star \star}$ &, $643^{* *}$ &, $786^{*}$ & 1 &, $701^{\star \star}$ \\
\hline & Sig. (2-tailed) & , 000 & ,000 &, 000 & & ,000 \\
\hline & $\mathrm{N}$ & 50 & 50 & 50 & 50 & 50 \\
\hline \multirow[t]{3}{*}{ Kinerja } & Pearson Correlation &, $559^{*}$ &, $553^{\star *}$ & ,614** &, $701^{* *}$ & 1 \\
\hline & Sig. (2-tailed) &, 000 & ,000 & ,000 &, 000 & \\
\hline & $\mathrm{N}$ & 50 & 50 & 50 & 50 & 50 \\
\hline
\end{tabular}

${ }^{* *}$. Correlation is significant at the 0.01 level (2-tailed).

Berdasarkan tabel 7 dapat diketahui hubungan atau korelasi antar variabel sebagai berikut Kepemimpinan dengan motivasi adalah 0,481 dan sig 0,000 dapat diartikan bahwa hubungan antara 
kepemimpinan dengan motivasi kuat dan signifikan. Lingkungan kerja dengan motivasi adalah 0,643 dan sig 0,000 dapat diartikan bahwa hubungan antara lingkungan kerja dengan motivasi kuat dan signifikan. Kompetensi dengan motivasi adalah 0,786 dan sig 0,000 dapat diartikan bahwa hubungan antara kompetensi dengan motivasi kuat dan signifikan. Kepemimpinan dengan Kinerja adalah 0,559 dan sig 0,000 dapat diartikan bahwa hubungan antara kepemimpinan dengan kinerja kuat dan signifikan. Lingkungan kerja dengan Kinerja adalah 0,553 dan sig 0,000 dapat diartikan bahwa hubungan antara lingkungan kerja dengan kinerja kuat dan signifikan. Kompetensi dengan Kinerja adalah 0,614 dan sig 0,000 dapat diartikan bahwa hubungan antara kompetensi dengan Kinerja kuat dan signifikan.

\section{Pengaruh Langsung, Pengaruh Tidak Langsung dan Total Pengaruh}

Untuk mengetahui adanya pengaruh langsung maupun tidak langsung hubungan antara kepemimpinan, lingkungan kerja dan kompetensi terhadapkinerja melalui motivasi kerja dapat dilihat pada tabel berikut.

Tabel 8. Hasil Rakapitulasi Jalur Total

\begin{tabular}{|c|c|c|c|c|c|c|}
\hline \multirow{2}{*}{ No. } & \multirow{2}{*}{ Arah Hubungan } & \multicolumn{2}{|c|}{ Regresi } & \multicolumn{2}{|c|}{ Korelasi } & \multirow{2}{*}{$\varepsilon$} \\
\hline & & Beta & Sig & $\mathrm{R}$ & Sig & \\
\hline 1 & Kepemimpinan $\rightarrow$ Motivasi & 0,005 & 0,966 & 0,481 & 0,000 & \multirow{3}{*}{0,582} \\
\hline 2 & Lingkungan Kerja $\rightarrow$ Motivasi & 0,259 & 0,039 & 0,643 & 0,000 & \\
\hline 3 & Kompetensi $\rightarrow$ Motivasi & 0,626 & 0,000 & 0,786 & 0,000 & \\
\hline 4 & Kepemimpinan $\rightarrow$ Kinerja & 0,270 & 0,043 & 0,559 & 0,000 & \multirow{4}{*}{0,662} \\
\hline 5 & Lingkungan Kerja $\rightarrow$ Kinerja & 0,017 & 0’908 & 0,553 & 0,000 & \\
\hline 6 & Kompetensi $\rightarrow$ Kinerja & 0,073 & 0.661 & 0,614 & 0,000 & \\
\hline 7 & Motivasi $\rightarrow$ Kinerja & 0,503 & 0,005 & 0,701 & 0,000 & \\
\hline
\end{tabular}

Tabel 9. Pengaruh langsung, pengaruh tidak langsung dan total pengaruh Kepemimpinan, Lingkungan Kerja, Kompetensi danMotivasipada Kinerja

\begin{tabular}{|c|c|c|c|c|}
\hline & Pengaruh & Langsung & Tidak Langsung & Total Pengaruh \\
\hline \multirow{3}{*}{ Model 1} & Kepemimpinan $\rightarrow$ Kinerja & 0,270 & & \\
\hline & Lingkungan Kerja $\rightarrow$ Kinerja & $0,017 * *$ & & \\
\hline & Kompetensi $\rightarrow$ Kinerja & $0,073 * *$ & & \\
\hline \multirow{4}{*}{ Model 2} & $\begin{array}{l}\text { Kepemimpinan } \rightarrow \text { motivasi } \rightarrow \\
\text { Kinerja }\end{array}$ & & $\begin{array}{l}0,005 \times 0,503^{* *} \\
=0,003\end{array}$ & \\
\hline & $\begin{array}{l}\text { Lingkungan Kerja } \rightarrow \text { motivasi } \\
\rightarrow \text { Kinerja }\end{array}$ & & $\begin{array}{l}0,259 * * \times 0,503 * * \\
=0,130 * *\end{array}$ & \\
\hline & $\begin{array}{l}\text { Kompetensi } \rightarrow \text { motivasi } \rightarrow \\
\text { Kinerja }\end{array}$ & & $\begin{array}{l}0,626^{* *} \times 0,503 * * \\
=0,315^{* *}\end{array}$ & \\
\hline & $\begin{array}{l}\text { Pengaruh total kepemimpinan } \\
\rightarrow \text { Kinerja melalui motivasi }\end{array}$ & & & $\begin{array}{l}0,270+0,003 \\
=0,273\end{array}$ \\
\hline
\end{tabular}




\begin{tabular}{|l|l|l|l|}
\hline $\begin{array}{l}\text { Pengaruh total lingkungan } \\
\text { kerja } \rightarrow \text { Kinerja melalui } \\
\text { motivasi }\end{array}$ & & & $\begin{array}{l}0,017+0,130 \\
=0,017\end{array}$ \\
\hline $\begin{array}{l}\text { Pengaruh total kompetensi } \rightarrow \\
\text { Kinerja melalui motivasi }\end{array}$ & & & $\begin{array}{l}0,703+0,315 \\
=1,018\end{array}$ \\
\hline
\end{tabular}

Pengaruh langsung

Kepemimpinan berpengaruh positif dan signifikan terhadap kinerja pegawai dengan nilai koefisien sebesar $0,270^{* *}$. Lingkungan kerja berpengaruh positif dan signifikan terhadap kinerja pegawai dengan nilai koefisien sebesar 0,017. Kompetensi berpengaruh positif dan signifikan terhadap kinerja pegawai dengan nilai koefisien sebesar 0,073 .

Pengaruh tidak langsung

Pengaruh kepemimpinan terhadap motivasi kerja signifikan dan pengaruh motivasi kerja terhadap kinerja karyawan signifikan, sehingga pengaruh tidak langsung $=0,003$. Pengaruh lingkungan kerja terhadap motivasi kerja signifikan dan pengaruh motivasi kerja terhadap kinerja karyawan signifikan, sehingga pengaruh tidak langsung $=0,130$. Pengaruh kompetensi terhadap motivasi kerja signifikan dan pengaruh motivasi kerja terhadap kinerja karyawan signifikan, sehingga pengaruh tidak langsung $=0,315$

\section{Pengaruh total}

Pengaruh total kepemimpinan terhadap kinerja melalui motivasi kerja sebesar 0,273. Pengaruh lingkungan kerja terhadap kinerja melalui motivasi kerja sebesar 0,017. Pengaruh kompetensi terhadap kinerja melalui motivasi kerja sebesar 1,018.

Hasil analisis jalur secara lengkap dalam penelitian ini daspat dijelaskan secara rinci mengenai pengaruh dan hubungan antar variabel penelitian pada gambar IV.1 yaitu :

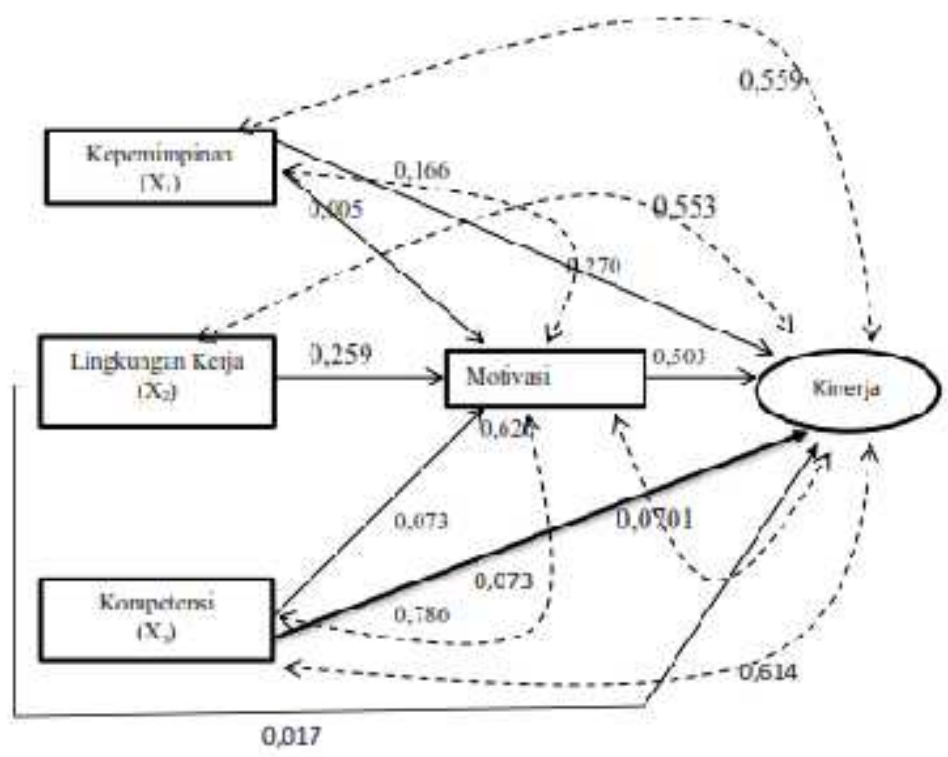

Gambar 2. Hasil Analisis Jalur 


\section{Implikasi Manajerial}

1. Pengaruh Kepemimpinan terhadap motivasi kerja dan kinerja karyawan

Berdasarkan analisis pengaruh langsung dan tidak langsung menunjukkan bahwa jalur tidak langsung variabel kepemimpinan berpengaruh positif dan signifikan terhadap kinerja pegawai melalui motivasi kerja pada karyawan hotel Sahid Jaya Solo. Upaya peningkatan peran kepemimpinan yang mampu meningkatkan kinerja karyawan yaitu : a) Penerapan gaya kepemimpinan yang disesuaikan atau dapat diterima setiap karyawan. b) Pimpinan perlu memberi keleluasaan dalam berkarya, berekspresi dan mengeluarkan pendapat serta gagasan kepada karyawan. c) Keputusan yang diambil pemimpin hendaknya dikaitkan atau disesuaikan dengan kebutuhan karyawan.

Untuk meningkatkan motivasi kerja dalam menunjang atau meningkatkan kinerja. Untuk itu perlu direkomendasikan beberapa langkah konkrit yaitu : a) Pimpinan menanamkan sikap kepada karyawan untuk selalu suka dan tekun dalam bekerja. b) Pimpinan menekankan pada karyawan untuk tidak suka menunda-nunda pekerjaan. c) Pimpinan menekankan pada karyawan untuk selalu menghargai pendapat orang lain

\section{Pengaruh lingkungan kerja terhadap motivasi kerja dan kinerja karyawan}

Berdasarkan analisa pengaruh langsung dan tidak langsung menunjukkan bahwa jalur langsung lingkungan kerja berpengaruh positif dan signifikan terhadap kinerja karyawan Hotel Sahid Jaya Solo. Untuk itu dibutuhkan peningkatan lingkungan kerja yang paling berperan dalam membentuk lingkungan kerja di dalam meningkatkan kinerja karyawan. Langkah-langkah konkrit yang dilakukan sebagai berikut : a) Ketersediaan lingkungan tempat kerja bekerja tidak ramai, baik untuk konsentrasi kerja. b) Ketersediaan penerangan (pencahayaan) ruang kerja yang ada di kantor tempat Bapak/Ibu bekerja cukup terang. c) Penataan Setting ruangan di kantor Bapak/Ibu memberikan kenyamanan dalam bekerja.

\section{Pengaruh kompetensi terhadap motivasi kerja dan kinerja karyawan}

Berdasarkan analisa pengaruh langsung dan tidak langsung menunjukkan bahwa jalur tidak langsung kompetensi berpengaruh positif dan signifikan terhadap kinerja karyawan Hotel Sahid Jaya Solo. Untuk itu dibutuhkan peningkatan kompetensi yang paling berperan dalam membentuk kompetensi di dalam meningkatkan kinerja karyawan. Langkah-langkah konkrit yang dilakukan sebagai berikut : a) Peningkatan terhadap pemahaman Standar Operasional Prosedur pekerjaan. b) Meningkatkan kemampuan untuk melakukan analisa hasil kerja karyawan. c) Meningkatkan pemahaman terhadap karakteristik dan jenis pekerjaan karyawan

\section{KESIMPULAN DAN KETERBATASAN}

Kesimpulan dalam penelitian ini yaitu kepemimpinan dan lingkungan kerja berpengaruh tetapi tidak signifikan terhadap motivasi karyawan Hotel Sahid Jaya Solo sedangkan kompetensi berpengaruh signifikan terhadap motivasi karyawan. Kepemimpinan, lingkungan kerja dan kompetensi berpengaruh tetapi tidak signifikan terhadap kinerja karyawan Hotel Sahid Jaya Solo. Motivasi berpengaruh signifikan terhadap kinerja karyawan Hotel Sahid Jaya Solo. Hasil analisis jalur menunjukkan bahwa variabel yang dipilih dalam meningkatkan kinerja adalah dengan meningkatkan kompetensi, karena kompetensi merupakan variabel yang paling dominan terhadap kinerja, dengan koefisien regresi $=1,018$ dimana koefisien yang tertinggi diantara yang lain.

Keterbatasan Penelitian dalam penelitian ini yaitu 1) kurangnya karakteristik responden yang diambil karena sampel hanya diambil dari satu perusahaan, sehingga hasil penelitian tidak dapat digunakan untuk menggeneralisasi pada perusahaan lain yang sejenis. 2) variabel yang digunakan dalam penelitian adalah 
variabel kepemimpinan, lingkungan kerja, kompetensi, motivasi kerja dan kinerja karyawan, ada kemungkinan variabel-variabel lain yang berpengaruh terhadap variabel kinerja, misalnya variabel disiplin kerja dan pemberian insentif.

\section{DAFTAR PUSTAKA}

Adriyanto, H., \& Subakti, A. G. (2018). Pengaruh Pelatihan, Motivasi dan Kompetensi Terhadap Kinerja Karyawan (Studi Kasus Hotel Sahid Jaya Lippo Cikarang). Journal of Indonesian Tourism, Hospitality and Recreation, 1(2), 55-69. https://doi.org/10.17509/jithor.v1i2.13767

Andayani, I., \& Tirtayasa, S. (2019). Pengaruh Kepemimpinan, Budaya Organisasi, Dan Motivasi Terhadap Kinerja Pegawai. Maneggio: Jurnal Ilmiah Magister Manajemen, 2(1), 45-54. https://doi.org/10.30596/maneggio.v2i1.3367

Aryono, I. A. (2017). Pengaruh Kepemimpinan dan Lingkungan Kerja terhadap Kinerja Karyawan pada PT. KAI DAOP 6 Yogyakarta dengan variabel Motivasi sebagai intervening. UII Yogyakarta.

Astuti, A. D. (2017). Pengaruh motivasi dan disiplin kerja terhadap kinerja guru SD di Kabupaten Cilacap. Jurnal Akuntabilitas Manajemen Pendidikan, 5(2), 150. https://doi.org/10.21831/amp.v5i2.13931

Bahri, S., \& Chairatun Nisa, Y. (2017). Pengaruh Pengembangan Karir Dan Motivasi Kerja Terhadap Kepuasan Kerja Karyawan. Jurnal Ilmiah Manajemen Dan Bisnis, 18(1), 9-15. https://doi.org/10.30596/jimb.v18i1.1395

Basori, M. ., Prahiawan, W., \& Daenulhay. (2017). Pengaruh Kompetensi Karyawan Dan Lingkungan Kerja Dan Terhadap Kinerja Karyawan Melalui Motivasi Kerja Sebagai Variabel Intervening. Jurnal Ekonomi, Vol 1 No 1, 149-158.

Daswati. (2012). Implementasi peran kepemimpinan dengan gaya kepemimpinan menuju kesuksesan organisasi. Academica Fisip Untad, 04(01), 783-798.

Febrian, W. D., Zulhaida, Z., \& Ilosa, A. (2019). Analisis Pengaruh Lingkungan Kerja Terhadap Kinerja Pegawai Bank Riau Kepri Syariah Pekanbaru. Syarikat: Jurnal Rumpun Ekonomi Syariah, 2(2). https://doi.org/10.25299/syarikat.2019.vol2(2).4782

Flippo, E. B. (2004). Manajemen Personalia. Ghalia Indonesia.

Hasibuan, M. (2009). Manajemen Dasar, Pengertian, dan Masalah. Bumi Aksara.

Marjaya, I., \& Pasaribu, F. (2019). Pengaruh Kepemimpinan, Motivasi, Dan Pelatihan Terhadap Kinerja Pegawai. Maneggio: Jurnal Ilmiah Magister Manajemen, 2(1), 129-147. https://doi.org/10.30596/maneggio.v2i1.3650

Muzakki, M., \& Ariyanto, S. Y. (2019). Manajemen Strategik Dalam Penilaian Kinerja. NUR EL-ISLAM : Jurnal Pendidikan Dan Sosial Keagamaan, 6(1), 171-182. https://doi.org/10.51311/nuris.v6i1.123

Nugroho, A., Tanoyo, K., \& Yudha w., T. (2013). Pengaruh Lingkungan Kerja Terhadap Kinerja Karyawan Hotel Majapahit Surabaya. Journal of Chemical Information and Modeling, 53(9), 1689-1699. 
Putra, R., Ernila, Komardi, D., \& Suyono. (2019). Pengaruh Gaya Kepemimpinan, Motivasi, dan Budaya Organisasi Terhadap Kepuasan Kerja dan Kinerja Guru Pada SMKN 4 Pekanbaru. Procuratio: Jurnal Ilmiah Manajemen, 7(4), 470-483.

Ramadhanty, N. T., Hardi, \& Meilda Wiguna. (2019). Pengaruh Kompetensi, Independensi, Emotional Quotient dan Audit Tenure terhadap Kualitas Audit (Studi Empiris pada Auditor di Kantor Akuntan Publik Riau dan Kepulauan Riau). Jurnal Kajian Akuntansi Dan Auditing, 14(1), 49-60. https://doi.org/10.37301/jkaa.v14i1.8

Ruky, A. S. (2002). Sukses Sebagai Manajer Profesional Tanpa Gelar MM atau MBA. Gramedia Pustaka Utama.

Sabaruddin, S., \& Marissa, M. (2018). Pengaruh Kepemimpinan, Lingkungan Kerja Dan Disiplin Terhadap Kinerja Pegawai Kantor Uptp Balai Peningkatan Produktivitas Kendari. Mega Aktiva: Jurnal Ekonomi Dan Manajemen, 7(1). https://doi.org/10.32833/majem.v7i1.57

Santris, B. (2019). Pengaruh kepemimpinan dan komitmen organisasi terhadap kinerja guru dengan motivasi sebagai variabel intervening pada SMA Sutomo 1 Medan. Journal of Accounting \& Management Innovation, 3(2), 91-116.

Siahaan, S., \& Bahri, S. (2019). Pengaruh Penempatan, Motivasi, Dan Lingkungan Kerja Terhadap Kinerja Pegawai. Maneggio: Jurnal Ilmiah Magister Manajemen, 2(1), 16-30. https://doi.org/10.30596/maneggio.v2i1.3402

Siregar, Y. L. (2020). Pengaruh kompetensi, motivasi, disiplin kerja dan komitmen organisasi terhadap kinerja pegawai pada kantor pelayanan pajak pratama tapak tuan. Jurnal Magister Manajemen, 2(1), 85-92.

Supiyanto, Y. (2015). Pengaruh Kompensasi, Kompetensi dan Komitmen Organisasional Terhadap Kepuasan dan Kinerja. Jurnal Economia, 11(2), 118-131. 